\title{
Myxomycetes of the Scientific Herbarium Maria Eneyda P. K. Fidalgo (SP): species of Trichiaceae (Myxogastromycetidae, Trichiales)
}

\author{
Laise de Holanda Cavalcanti ${ }^{1,2}$, Andrea Carla Caldas Bezerra ${ }^{1}$, David Itallo Barbosa ${ }^{1}$, Vitor Xavier de Lima ${ }^{1}$ \\ and Antônia Aurelice Aurélio Costa ${ }^{1}$
}

Received: 21.10.2013; accepted: 27.05.2014

\begin{abstract}
Myxomycetes of the Scientific Herbarium Maria Eneyda P.K. Fidalgo (SP): species of Trichiaceae (Myxogastromycetidae, Trichiales). This article presents a review of the Trichiaceae collection of the SP Herbarium which holds 128 exsiccates mainly collected from Conservation Units of Atlantic Forest (Parque Nacional da Floresta da Tijuca and Parque Nacional do Itatiaia, Rio de Janeiro State; Parque Estadual das Fontes do Ipiranga and Reserva Biológica do Alto da Serra de Paranapiacaba, São Paulo State). Some specimens were collected from Amazon Forest (Pará and Rondônia States), Cerrado, (savanna-like vegetation), coastal environments, and urbanized areas (Minas Gerais and São Paulo States). The Trichiaceae collection is in well preserved conditions, with six genera and 15 species. Arcyria, with six species, represents $60 \%$ of all exsiccates. Arcyria denudata (L.) Wetts. is a new record for Pará State, enhancing the knowledge of this species geographic distribution in the Brazilian Amazon Region. A commented list of the species and exsiccates are provided herewith, including the typus of the genus Arcyriatella Hochg. \& Gottsb.
\end{abstract}

Keywords: Arcyriatella, biodiversity, biological collections, neotropics

RESUMO - (Myxomycetes do Herbário Científico do Estado Maria Eneyda P.K. Fidalgo (SP): espécies de Trichiaceae (Myxogastromycetidae, Trichiales). Este trabalho apresenta uma revisão da coleção de Trichiaceae do Herbário SP, que abriga 128 exsicatas coletadas principalmente em Unidades de Conservação de Floresta Atlântica (Parque Nacional da Floresta da Tijuca e Parque Nacional do Itatiaia, Rio de Janeiro; Parque Estadual das Fontes do Ipiranga e Reserva Biológica do Alto da Serra de Paranapiacaba, São Paulo). Alguns espécimes foram coletados em Floresta Amazônica (Pará e Rondônia), Cerrado, ambientes costeiros e áreas urbanizadas (Minas Gerais e São Paulo). A coleção de Trichiaceae encontra-se em boas condições de conservação, com seis gêneros e 15 espécies. Arcyria, com seis espécies, representa $60 \%$ de todas as exsicatas. Arcyria denudata (L.) Wetts. é um novo registro para o Estado do Pará, ampliando o conhecimento sobre a distribuição geográfica desta espécie na Amazônia brasileira. Uma lista comentada das espécies, incluindo o typus do gênero Arcyriatella Hochg. \& Gottsb., é fornecida.

Palavras-chave: Arcyriatella, biodiversidade, coleções biológicas, neotrópicos

\section{Introduction}

The nearly 900 species of Myxomycetes currently accepted are distributed in the subclasses Ceratiomyxomycetidae, Stemonitomycetidae and Myxogastromycetidae. The latter, with four orders, among which are the Trichiales which encompass almost $20 \%$ of overall species of its Class (Martin et al. 1983, Lado 2005-2013).

The order Trichiales contains the families Dianemataceae, with two genera and 15 species, and
Trichiaceae, with 12 genera and 160 species, both represented in Brazil's myxobiota (Lado 2005-2013, Cavalcanti 2013). Trichiaceae species are referred to the five regions of Brazil, distributed in the genera Arcyria (16 spp.), Arcyriatella (1 sp.), Hemitrichia (8 spp.), Metatrichia (2 spp.), Oligonema (2 spp.), Perichaena (5 spp.) and Trichia (10 spp.), occurring in the Amazon, Cerrado, Caatinga and Atlantic Forest biomes (Cavalcanti 2013).

As part of the project aimed at producing an inventory of the order Trichiales in Brazilian

1. Universidade Federal de Pernambuco, Departamento de Botânica, Laboratório de Myxomycetes, Av. Prof. Moraes Rego s.n., Cidade Universitária, 50670-901 Recife, PE, Brasil

2. Corresponding author: laise@pq.cnpq.br 
herbaria, which is supported by CNPq-PROTAX (Conselho Nacional de Desenvolvimento Científico e Tecnológico), we have analyzed the collection of the Scientific Herbarium Maria Eneyda P. K. Fidalgo (SP), located in the Instituto de Botânica, São Paulo, SP. Founded in 1917, the SP Herbarium contains a significant collection of angiosperms, pteridophytes, bryophytes, lichens and fungi from different regions of the country and is one of the few herbaria in Brazil that houses Myxomycetes exsiccates.

\section{Material and methods}

The 128 exsiccates of the Trichiaceae family were identified based on Martin \& Alexopoulos (1969), Farr (1976), Lado \& Pando (1997) and Poulain et al. (2011). Binomials were updated according to Lado (2005-2013).

The level of conservation of each specimen was evaluated (table 1, figures 1-5) according to criteria described by Cavalcanti et al. (2014) and entered into the list of exsiccates, right after its registration number at the SP Herbarium. The known distribution of the species in Brazil's southeastern region was based upon Cavalcanti (2013).

\section{Results and Discussion}

Six genera and 27 species of Trichiaceae have been known to occur in the southeastern region of Brazil, particularly in São Paulo State, in which myxobiota is one of the best explored in the country (Hochgesand \& Gottsberger 1996). In the collection of the SP Herbarium, six genera and 15 species are represented, with exsiccates collected mainly in the southeastern region, in the States of São Paulo (86\%), Rio de Janeiro (5.30\%) and Minas Gerais (0.76\%),

Table 1. Criteria adopted to establish the level of conservation of Myxomycetes exsiccates of the Scientific Herbarium Maria Eneyda P. K. Fidalgo (SP).

\begin{tabular}{cl}
\hline Level & Description \\
\hline 1 & $\begin{array}{l}\text { No traces of sporocarps } \\
2\end{array}$ \\
$\begin{array}{l}\text { Exhibiting only stalks and/or hypothallus of the } \\
\text { sporocarps originally collected }\end{array}$ \\
3 & $\begin{array}{l}\text { Heavily damaged sporocarps, precluding } \\
\text { identification }\end{array}$ \\
4 & Exsiccate containing $\geq 2$ complete sporocarps \\
5 & $\begin{array}{l}\text { Exsiccate containing } \geq 80 \% \text { of its sporocarps in } \\
\text { good conservation }\end{array}$ \\
\hline
\end{tabular}

within biomes such as Atlantic Forest (Restinga Forest, Semi-deciduous Seasonal forest, Dense Ombrophilous Forest) and Cerrado. Eight specimens were collected in the Amazon biome, in the country's northern region, with two in the microregion of Óbidos, in Pará State and six in Rondônia State, in the Reserva Biológica de Jarú, within an environment of Open Ombrophylous Forest. Only a single exsiccate (A. denudata (L.) Wetts., SP 107298) comes from abroad (Maryland-USA).

Although the oldest exsiccate dates back to 1933, the three most recent ones were only collected in 1991 and the collection has not received new materials for nearly 20 years. The specimens are packaged in cardboard boxes and close to $60 \%$ of them have well-preserved sporocarps which allowed either the identification or confirmation of the species (figure 6). The exsiccate labels include the following data: State, municipality, locality and collection date, sporulation substrate, collector and determiner.

The majority of exsiccates (90\%) were identified on a species level, 5.3\% had their binomials updated and about $4 \%$ were re-determined. The number of exsiccates per species varies between 1 and 57 and the four most commonly represented binomials are Arcyria denudata (L.) Wetts. (57), Hemitrichia calyculata (Speg.) M. L. Farr (21), H. serpula (Scop.) Rostaf. (16) and A. cinerea (Bull.) Pers. (15).

The collection is small but it stands out for containing 59 specimens collected in São Paulo State, within environments such as restinga, cerrado, rainforest and urban areas by Gerhard K. Gottsberger during his stay in Brazil in the 1960's and 1970's, in which the following genera were represented: Arcyria, Arcyriatella, Hemitrichia, Perichaena and Trichia. Aside from that, it also contains the first specimens of Myxomycetes collected in Rondônia State during expeditions conducted in the 1980's in the Reserva Biológica de Jarú, Ji-Paraná microregion; and exsiccates SP 233765 and SP 177513 are the first records of the occurrence of $A$. denudata for Pará State, collected in the mesoregion of the Lower Amazon.

\section{List of the species}

\section{Arcyria F.H. Wigg.}

The 77 Arcyria exsiccates are well-preserved (levels 4 and 5) and the genus is represented by six species, which correspond to $54.5 \%$ of those that 
have occurrence records in the State of São Paulo (Hochgesand \& Gottsberger 1996, Cavalcanti 2013). The level of conservation of exsiccates SP142161, SP142161 and SP142179, collected in Mogi-Guaçu, SP, has not allowed the species identification.

1. A. cinerea (Bull.) Pers., Syn. meth. fung. 1:184. 1801.

Exsiccates with confirmed identification (14) BRAZIL. Rio DE JANEIRo: Rio de Janeiro, Jardim Botânico, 19-III-1957, O. Fidalgo \& M.E.P.K. Fidalgo (SP70628) [4]; Tijuca Forest, 28-III-1957, O. Fidalgo \& M.E.P.K. Fidalgo (SP70666) [5]. São PAULO: Botucatu, Estação velha do trem, 17-I-1974, G.K. Gottsberger (SP233550) [5]; idem, collection location not informed, 4-VI-1970, G.K. Gottsberger (SP233569) [3]; idem, Rubião Júnior, 16-V-1970, G.K. Gottsberger (SP233571) [4]; Itanhaem, collection location not informed, 22-VII-1969, Anonimous (SP233557) [3]; Pardinho, Sítio Pardinho, 7-I-1974, G.K. Gottsberger (SP233575) [2]; Piracicaba, collection location not informed, 15-IV-1972, A.I. Milanez (SP112166) [1]; São Paulo, Parque do Estado, Instituto de Botânica, 7-X-1966, B. Skvortzov (SP97566) [4]; idem, B. Skvortzov (SP97567) [1]; idem, collecting day not informed, B. Skvortzov (SP233572) [3]; idem, collecting day not informed, B. Skvortzov (SP233573) [3]; idem, 25-IX-1966, G.K. Gottsberger (SP106694) [2]; idem, Chácara Flora, 26-XI-1967, Anonymous (SP233574) [5].

Identified exsiccate (1) - BRAZIL. São PaUlo: Santo André, Reserva do Alto da Serra de Paranapiacaba, 8-I-1991, L.K. Okino \& M. Capelari (SP233766) [5]. Distribution in the southeastern region of Brazil: Minas Gerais, Rio de Janeiro and São Paulo States.

2. A. denudata_(L.) Wettst., Verh. Zool.-Bot. Ges. Wien 35:535. 1886.

Exsiccates with confirmed identification (46) - USA. MARYLAND: Brandiwine, old stump near Brandiwine, 12-XI-1933, C.S. Parker \& A.L. Parker (SP107298) [5]. BRAZIL. Rio DE JANEIRO: Rio de Janeiro, Jardim Botânico, 19-III-1957, O. Fidalgo \& M.E.P.K. Fidalgo (SP70569) [4]; idem, O. Fidalgo \& M.E.P.K. Fidalgo (SP70660) [5]. São Paulo: São Paulo, Pinheiros, 26-XII-1933, A. Gehrt (SP32543) [4]; idem, Parque do Estado, Instituto de Botânica, 1-II-1960, O. Fidalgo, M.E.P.K. Fidalgo \& J.S. Furtado (SP46758) [3]; idem, Picada Loefgren, IV-1960, O. Fidalgo \& J.S. Furtado.

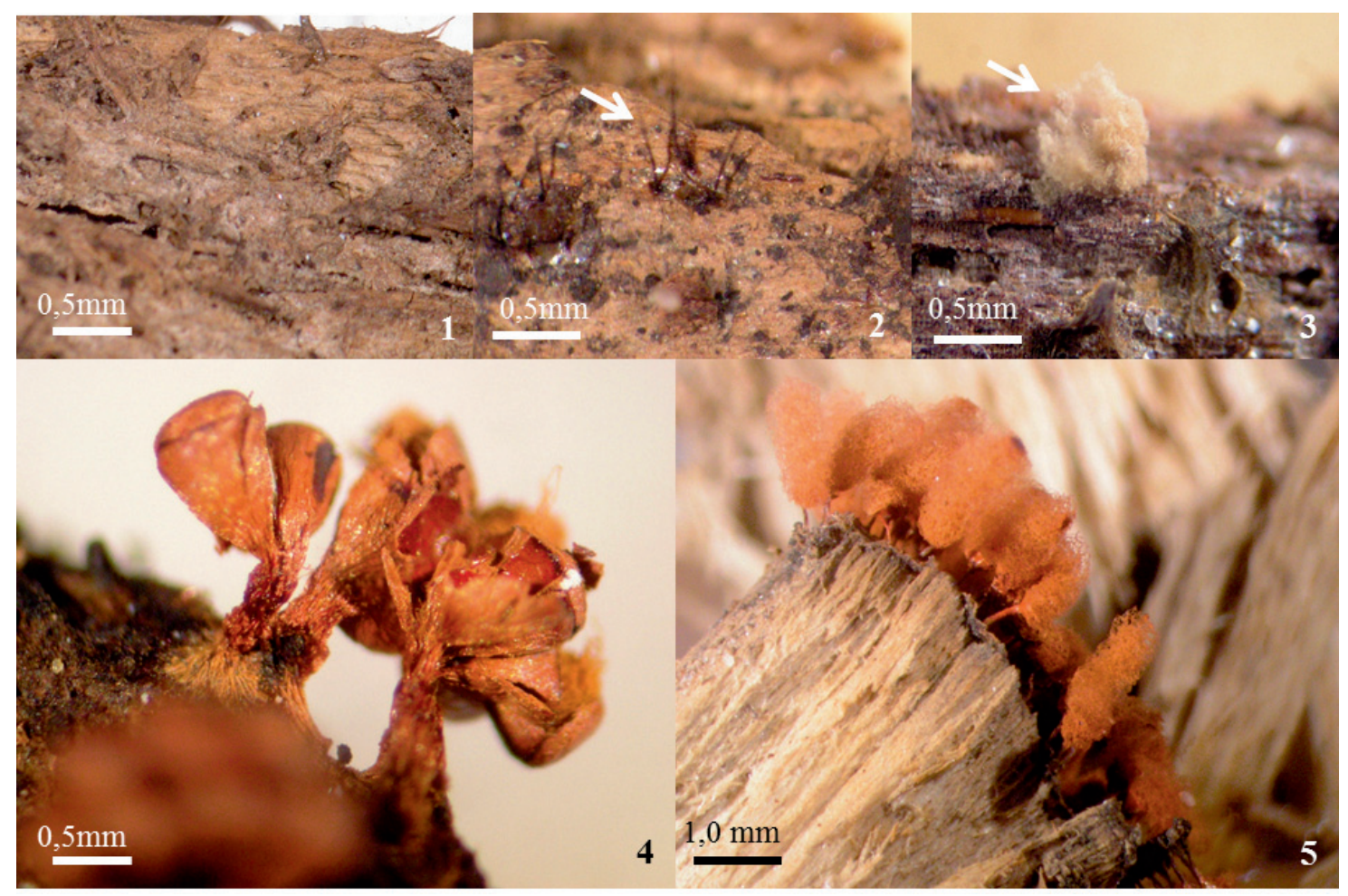

Figures 1-5. Levels of conservation of exsiccates: 1. No traces of sporocarps on the substrate. 2. Exsiccate exhibiting only stalks of the sporocarps originally collected (see arrow). 3. Heavily damaged sporocarps, precluding identification (see arrow). 4. Exsiccate containing $\geq$ 2 complete sporocarps. 5 . Exsiccate containing $\geq 80 \%$ of the sporocarps originally collected in good level of conservation. 
(SP49005) [5]; idem, Picada Gardner, 7-III-1962, A.R. Salles (SP62003) [3]; idem, 1-V-1963, B. Skvortzov (SP62146) [3]; idem, 28-IV-1967, B. Skvortzov (SP84064) [5]; idem, 9-XI-1966, H. Requejo (SP97686) [4]; idem, 18-X-1966, H. Requejo (SP97690) [5]; idem, 25-X-1966, G.K. Gottsberger (SP106695) [4]; idem, XII-1966, B. Skvortzov (SP233475) [4]; idem, 7-X-1966, G.K. Gottsberger (SP233482) [5]; idem, 28-XI-1967, G.K. Gottsberger (SP233477) [4]; idem, 15-XII-1967, B. Skvortzov (SP233478) [5]; idem, 1-XII-1967, B. Skvortzov (SP233479) [5]; idem, 1-IV-1968, G.K. Gottsberger (SP233558) [2]; Campos do Jordão, near hotel Toriba, 13-XI-1966, G.K. Gottsberger (SP233487) [1]; Mogi-Guaçu, Campininha Farm, 29-IX-1967, G.K. Gottsberger (SP233469) [4]; São Paulo, Chácara Flora, 26-XI-1967, G.K. Gottsberger (SP233466) [2]; idem, 2-XI-1967, G.K. Gottsberger (SP233489) [1]; idem, Eldorado, 21-IX-1966, G.K. Gottsberger (SP106699) [2]; Ubatuba, Miranduba beach, 12-IV-1968, G.K. Gottsberger (SP233567) [3]; Itanhaem, collection location not informed, 3-X-1968, G.K. Gottsberger (SP233481) [3]; idem, morro da igreja, 31-XII-1968, G.K. Gottsberger (SP233488) [1]; Botucatu, collection location not informed, 4-VI-1970, G.K. Gottsberger (SP233559) [4]; idem, 1-IV-1970, G.K. Gottsberger (SP233563) [3]; idem, Estrada para São Manoel, 29-VIII-1970, G.K. Gottsberger (SP233564) [3]; idem, Rubião Júnior, Fazenda Bertignolli, 18-IV-1970, G.K. Gottsberger (SP233562) [3]; idem, 16-V-1970, G.K. Gottsberger (SP233565) [5]; idem, 25-IV-1970, G.K. Gottsberger (SP233566) [2]; idem, collection location not informed, 17-I-1974, G.K. Gottsberger (SP233476) [2]; Santo André, Paranapiacaba, Reserva Biológica de Paranapiacaba, 12-IV-1988, M. Capelari \& R.C.P. Santos (SP214800) [5]; idem, 9-VIII-1988, R.A.P. Grandi. (SP250404) [5]; idem, 8-I-1991, L.K. Okino \& M. Capelari (SP233729) [1];

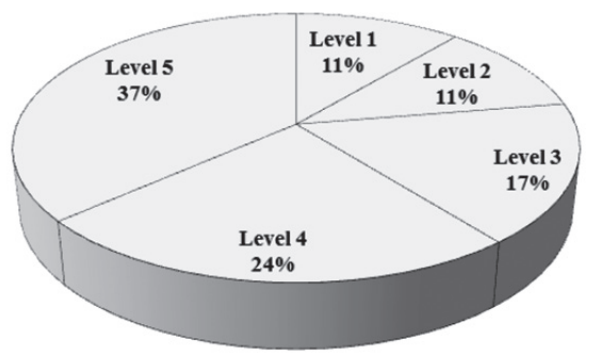

Figure 6. Levels of conservation of Trichiaceae exsiccates deposited in the Myxomycetes collection of the Scientific Herbarium Maria Eneyda P. K. Fidalgo (SP). idem, L.K. Okino \& M. Capelari (SP233765) [5]. PARÁ: Oriximiná, collection location not informed, 26-VI-1980, V.L.R. Bononi (SP177513) [4]; idem, Cachoeira Porteira, V.L.R. Bononi (SP193899) [1]. RonDôNIA: Jarú, margem direita do Igarapé Paraíso, 2-X-1986, M. Capelari \& R. Maziero (SP194355) [5]; idem, collection location not informed, M. Capelari \& R. Maziero (SP211222) [5]; idem, Reserva do Jarú, margem direita do rio Ji-Paraná, 12-V-1987, M. Capelari \& R. Maziero (SP212047) [5]; idem, 18-V-1987, M. Capelari \& R. Maziero (SP212040) [5]; idem, M. Capelari \& R. Maziero (SP212044) [5]; idem, M. Capelari \& R. Maziero (SP212048) [5].

Redetermined exsiccates (2) - BRAZIL. São PAULO: Botucatu, estação velha do trem, 29-I-1976, R.C.S. Maimoni-Rodella \& G. Gottsberger (SP233474) [3]; originally identified with doubts by M. L. Farr as A. incarnata the specimen can be told apart from this species on the basis of the capillitium, which remains attached after expanding, and the deep and funnel-shaped calyculus; idem, Piracicaba, collection location not informed, 15-V-1972, A.I. Milanez (SP 112158) [4], originally identified as A. stipata (L.) Wettst.; the specimen shows the distinct features of A. denudata: reddish-brown sporangia, funnel-shaped calyculus and capillitium with many attachments to the calyculus, decorated with cogs, half rings and rings with irregular edges.

Identified exsiccates (9) - BRAZIL. SÃo PAULO: São Paulo, Serra da Cantareira, 13-I-1966, M.C. Marino (SP83932) [5]; idem, Parque Estadual, Instituto de Botânica, 25-IV-1969, B. Skvortzov (SP103961) [4]; Caraguatatuba, Mococa beach, 24-X-1969, I.P. Sazima \& P. Montouchet (SP107123) [2]; Paranapiacaba, Reserva Biológica de Paranapiacaba, 15-IV-1972, A.I. Milanez (SP112159) [4]; idem, collection location not informed, 15-IV-1972, A.I. Milanez (SP112158) [5]; São Paulo, Parque do Estado, 9-IV-1974, A.L. Camargo (SP124292) [4]; idem, Parque do Estado, Instituto de Botânica, 18-XI-1976, O. Yano (SP141555) [5]; Cananéia, Ilha do Cardoso, near Marujá beach, 13-IX-1977, R.A. Píccolo (SP141760) [5]; São Paulo, Parque do Estado, 12-IV-1978, S.F.B. Trufem (SP142084) [4].

Distribution in the southeastern region of Brazil: Rio de Janeiro and São Paulo States.

\section{A. ferruginea Saut., Flora 24:316. 1841.}

Exsiccates with confirmed identification (1) BRAZIL. São PAulo: São Paulo, Parque do Estado, 
Instituto de Botânica, 6-XII-1968, G. Gottsberger (SP233473) [4].

Distribution in the southeastern region of Brazil: Rio de Janeiro and São Paulo States.

4. A. incarnata (Pers. ex J.F. Gmel.) Pers., Observ. mycol. 1: 58. 1796.

Exsiccate with confirmed identification (1) - BRAZIL. São Paulo: São Paulo, Parque Estadual, collection date not informed, B. Skvortzov (SP233470) [4].

Distribution in the southeastern region of Brazil: São Paulo State.

5. A. insignis Kalchbr. \& Cooke, in Kalchbrenner, Grevillea 10:143. 1882.

Redetermined exsiccate (1) - BRAZIL. São Paulo: Santo André, Reserva do Alto da Serra de Paranapiacaba, 8-I-1991, L.K. Okino \& M. Capelari (SP233765) [5]; originally identified as $A$. denudata by L. K. Okino. The most useful features to separate A. insignis from $A$. denudata are their minute sporangia of pinkish hues (1-2 $\mathrm{mm}$ high vs. $2-4 \mathrm{~mm}$ in A. denudata after expansion of the capillitium), usually disposed in small groups, and capillitium markings (rings and half-rings instead of warts, spines, cogs, ridges and rings with irregular edges).

Distribution in the southeastern region of Brazil: Rio de Janeiro and São Paulo States.

6. A. obvelata (Oeder) Onsberg, Mycologia 70(6):1286. 1979.

Exsiccate with confirmed identification (1) - BRAZIL. State, municipality and collection location not informed, 3-X-1968, G.K. Gottsberger (SP233472) [4].

Identified exsiccate (1) - BRAZIL. São Paulo: São Paulo, Parque do Estado, Instituto de Botânica, 8-IV-1968, A.I. Milanez (SP102311) [5].

Distribution in the southeastern region of Brazil: São Paulo State.

\section{Arcyriatella Hochg. \& Gottsb.}

The monotypic genus Arcyriatella, proposed by Hochgesand \& Gottsberger (1989), is only known for its type-locality, a Conservation Unit of Atlantic Forest comprising 526,38 hectares, located in the municipality of São Paulo (233 $38^{\prime} 08^{\prime \prime}-23^{\circ} 40^{\prime} 18^{\prime \prime}$ S and $46^{\circ} 36^{\prime} 48^{\prime \prime}-46^{\circ} 38^{\prime} 00^{\prime \prime} \mathrm{W}, 770-825 \mathrm{~m}$ alt.), with close to 345 ha of forest where species that are typically both of Semi-deciduous Seasonal Forest and of the Dense Ombrophylous Forest (Penhalber \& Montovani 1997). The typus of A. congregata, deposited in the SP Herbarium collection is well-preserved (figure 7), showing two rusty-red pseudoaethalia, a well-developed silver hypothallus, and typical spores arranged in groups of 3 to 10 .

1. A. congregata Hochg. \& Gottsb., Nova Hedwigia 48(3-4): 486. 1989.

Exsiccate with confirmed identification (1) - BRAZIL. São PaUlo: São Paulo, Parque do Estado, Instituto de Botânica, 28-XI-1967, G.K. Gottsberger (SP214877) [5].

Distribution in the southeastern region of Brazil: São Paulo State.

\section{Hemitrichia Rostaf.}

There are 37 Hemitrichia exsiccates in the SP Herbarium's collection, almost all belonging to levels 4 and 5, that represent two of the three species known to occur in the São Paulo State (Cavalcanti 2013).

1. H. calyculata (Speg.) M.L. Farr, Mycologia 66 (5): 887.1974.

Updated binomials (5) - BRAZIL. Rio DE JANEIRO: Itatiaya, Parque Nacional, Maromba, Véu de noiva, 18-IX-1955, O. Fidalgo \& M.E.P.K. Fidalgo (SP55862) [5]; Rio de Janeiro, Jardim Botânico, 19-III-1952, O. Fidalgo \& M.E.P.K. Fidalgo (SP70663) [1]. SÃO PAULO: São Paulo, Parque do Estado, Instituto de Botânica, 8-IX-1966, H. Requejo (SP97700) [4]; idem, 13-VII-1960, L.T.G. Eiten \& E. R. La Sota (SP51298) [5]; idem, collection location not informed, 9-XI-1966, H. Requejo (SP97675) [5].

Exsiccates with confirmed identification(15)-BRAZIL. São Paulo: Bofete, Oito Pontas Farm, 24-IV-1971, G.K. Gottsberger (SP233579) [4]; Botucatu, Rubião Junior, Bertignolli Farm, 28-X-1976, R.C.S. MaimoniRodella \& G. Gottsberger (SP233576) [4]; idem, R.C.S. Maimoni-Rodella \& G. Gottsberger (SP233577) [5]; idem, R.C.S. Maimoni-Rodella \& G. Gottsberger (SP233584) [4]; idem, R.C.S. Maimoni-Rodella \& G. Gottsberger (SP233587) [5]; idem, 11-XI-1976, R.C.S. Maimoni-Rodella \& G. Gottsberger (SP233580) [4]; idem, R.C.S. Maimoni-Rodella \& G. Gottsberger (SP233582) [4]; idem, 13-II-1976, R.C.S. Maimoni- 
Rodella \& G. Gottsberger (SP233583) [3]; idem, 18-IV-1970, G. Gottsberger (SP233460) [4]; idem, 11-XI-1976, G. Gottsberger (SP233591) [5]; idem, 22-IV-1970, G. Gottsberger (SP233578) [4]; idem, 14-IV-1970, G. Gottsberger (SP233581) [4]; Itanhaem, 23-VII-1969, G. Gottsberger (SP233485) [1]; idem, 3-X-1968, G. Gottsberger (SP233486) [4]; São Sebastião, 14-XI-1966, G. Gottsberger (SP233585) [2].

Identified exsiccate (1) - BRAZIL. São PAulo: São Paulo, Picada Gardner, Parque do Estado, Instituto de Botânica, 13-VII-1965, B. Skvortzov (SP95680) [4].

Distribution in the southeastern region of Brazil: Rio de Janeiro and São Paulo States.

2. H. serpula (Scop.) Rostaf. ex Lister, Monogr. mycetozoa, ed. 1 179. 1894.

Exsiccates with confirmed identification (14) BRAZIL. São Paulo: Botucatu, Rubião Júnior, Bertignolli Farm, 9-IV-1976, R.C.S. Maimoni-Rodella \& G. Gottsberger (SP233499) [5]; idem, 1-V-1970, G. Gottsberger (SP233501) [5]; idem, 29-VII-1976, R.C.S. Maimoni-Rodella (SP233502) [5]; idem, 14-IV-1970, G. Gottsberger (SP233500) [5]; idem, 22-IV-1970, G. Gottsberger (SP233538) [5]; idem, Morro da Igreja, 15-VIII-1970, G. Gottsberger (SP233543) [5]; São Paulo, Parque Estadual, Instituto de Botânica, 26-IX-1966, B. Skvortzov (SP97529) [5]; idem, 4-X-1966, H. Requejo (SP97688) [5]; idem, 24-XI-1966, B. Skvortzov (SP97796) [5]; idem, 28-XII-1966, B. Skvortzov (SP98014) [5]; idem, 9-I-1968, J.S. Furtado (SP102088) [5]; idem,

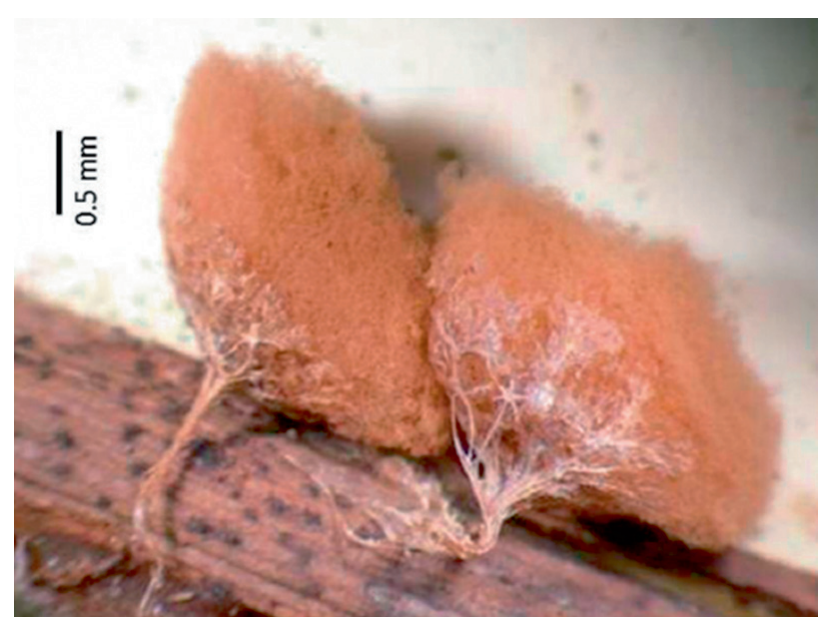

Figure 7. Holotypus of Arcyriatella congregata Hochg. \& Gotts. deposited in the Myxomycetes Collection of the Scientific Herbarium Maria Eneyda P. K. Fidalgo (SP).
29-XII-1969, B. Skvortzov (SP107241) [5]; idem, 27-IX-1966, G. Gottsberger (SP233471) [4]; Serra da Cantareira, 28-VIII-1956, A.R. Teixeira; M.E.P.K. Fidalgo \& O. Fidalgo (SP70669) [5].

Redetermined exsiccate (2) - BRAZIL. SÃo PAULO: Botucatu, Santo Antônio, 5-VIII-1975, G. Gottsberger (SP233535) [5], originally identified as H. calyculata, a very different species in general appearance, capillitium and spores; São Paulo, Parque do Estado, Instituto de Botânica, 6-X-1966, H. Requejo (SP97584) [5], originally identified as $P$. depressa; this specimen has the typical capillitium of $H$. serpula, decorated with 3-4 spinose spiral bands connected by longitudinal striae, long spines, and reticulate spores.

Distribution in the southeastern region of Brazil: Rio de Janeiro and São Paulo States.

\section{Metatrichia Ing}

Two exsiccates of the collection, one wellpreserved, belong to the Metatrichia genus and represent one out of the two species listed by Cavalcanti (2013) for São Paulo State.

1. M. floriformis (Schwein.) Nann.-Bremek., Proc. Kon. Ned. Akad. Wetensch., C. 88(1):127. 1985.

Updated binomials (2) - BRAZIL. São PAULo: São Paulo, Parque do Estado, Instituto de Botânica, 14-X-1966, H. Requejo (SP97634) [1], originally identified as Trichia floriformis (Schwein.) G. Lister; idem, Picada Gardner, VIII-1961, E.S. Benecke \& A.L. Rogers (SP61004) [5], originally identified as T. floriformis.

Distribution in the southeastern region of Brazil: São Paulo State.

\section{Perichaena Fr.}

The SP Herbarium collection contains seven wellpreserved Perichaena exsiccates, in which two out of the three species that have a record of occurrence up to date in São Paulo State are represented (Cavalcanti 2013).

\section{P. chrysosperma (Curr.) Lister, Monogr. mycetozoa,} ed. 1 196. 1894.

Exsiccates with confirmed identification (3) - BRAZIL. São Paulo: São Paulo, Parque do Estado, Instituto de Botânica, 1-XII-1967, B. Skvortzov (SP233434) [4]; Campos do Jordão, near Toriba Hotel, 13-XI-1966, G. Gottsberger (SP233438) [1]; Ubatuba, Miranduba beach, 12-IV-1968, G. Gottsberger (SP233458) [4]. 
Distribution in the southeastern region of Brazil: Rio de Janeiro and São Paulo States.

\section{P. depressa Lib., Pl. crypt. Arduenna 378. 1837.}

Exsiccates with confirmed identification (4) BRAZIL. São Paulo: São Paulo, Parque do Estado, Instituto de Botânica, 25-IX-1966, G.K. Gottsberger (SP106693) [4]; idem, 10-V-1967, G. Gottsberger (SP233536) [5]; idem, Água Funda, 6-II-1968, L.T. Eiten (SP233463) [4]; idem, Mogi-Guacu, Campininha Farm, 30-IX-1967, G. Gottsberger (SP233530) [2].

Distribution in the southeastern region of Brazil: Rio de Janeiro and São Paulo States.

\section{Trichia Haller}

The five Trichia exsiccates of the SP Herbarium represent three of the six species listed by Cavalcanti (2013) for São Paulo State. Almost all of them are in a good state of conservation.

1. T. contorta (Ditmar) Rostaf., Sluzowce monogr. 259. 1875.

Exsiccates with confirmed identification (2) BRAZIL. São Paulo: Botucatu, estação velha de trem, 13 de maio, 12-II-1976, R.C.S. Maimoni-Rodella (SP233459) [1]; idem, Rubião Júnior, Bertignolli farm, 1-V-1970, G. Gottsberger (SP233561) [4].

Distribution in the southeastern region of Brazil: São Paulo State.

2. T. decipiens (Pers.) T. Macbr., N. Amer. Slimemoulds, ed. 1218.1899.

Exsiccate with confirmed identification (1) - BRAZIL. Minas Gerais: Brejo da Lapa, Estrada Agulha Negra, 4-IV-1966, J.S. Furtado (SP91424) [5].

Distribution in the southeastern region of Brazil: Minas Gerais and São Paulo States.

3. T. favoginea (Batsch) Pers., Neues Mag. Bot. 1:90. 1794.

Exsiccates with confirmed identification (2) BRAZIL. São Paulo: São Paulo, Parque do Estado, Instituto de Botânica, 8-VIII-1969, G. Gottsberger (SP233436) [5]; idem, 6-IV-1967, G. Gottsberger (SP233441) [1].

Distribution in the southeastern region of Brazil: Rio de Janeiro and São Paulo States.

\section{Acknowledgements}

The authors wish to thank the Curator of SP Herbarium, for the loan of exsiccates. They are also grateful to Conselho Nacional de Desenvolvimento Científico e Tecnológico (CNPq), for theirfinancial support (PROTAX) and productivity grant awarded to L.H. Cavalcanti (Proc. 305967/2009-6).

\section{Literature cited}

Capelari, M. \& Maziero, R. 1988. Fungos macroscópicos do Estado de Rondônia, região dos rios Jaru e Ji-Paraná. Hohenea 15: 28-36.

Cavalcanti, L.H. 2013. Trichiales. In: R. C. Forzza, A. Costa, B. M. T. Walter, J. R. Pirani, M. P. Morin, L. P. Queiroz, G. Martinelli, A. L. Peixoto, M. A. N. Coelho, J. F. A. Baumgratz, J. R. Stehmann, L. G. Lohmann \& M. Hoplins. Lista de espécies da Flora do Brasil. Jardim Botânico do Rio de Janeiro, Rio de Janeiro. Available in: http:// floradobrasil.jbrj.gov.br/2010. (access in: 12-IX-2013).

Cavalcanti, L. H., Santos-Cavalcanti, E. J., Barbosa, D. I., Agra, L. A. N. N., Bezerra, A. C. C. \& Costa, A. A. A. 2014. Myxomycetes collection preserved in the Herbarium of the Federal University of Roraima (Brazil). Acta Amazonica 44: 59-66.

Farr, M.L. 1976. Myxomycetes. Flora Neotropica. Monograph 16. New York Botanical Garden Press, New York.

Hochgesand, E. \& Gottsberger, G. 1989. Arcyriatella congregata, a new genus and species of the Trichiaceae (Myxomycetes). Nova Hedwigia 48: 485-489.

Hochgesand, E. \& Gottsberger, G. 1996. Myxomycetes from the State of São Paulo, Brazil. Boletim do Instituto de Botânica 10: 1-46.

Lado, C. 2005-2013. An on-line nomenclatural information system of Eumycetozoa. Available in: htpp://www. nomen.eumycetozoa.com. (Access in: 11-IX-2013).

Lado, C.\& Pando, F. 1997. Myxomycetes. I. Ceratiomyxales, Echinosteliales, Liceales, Trichiales. Flora Mycologica Iberica. v.2. Real Jardin Botánico, Madrid.

Martin, G.W. \& Alexopoulos, C. J. 1969. The Myxomycetes. University of Iowa Press, Iowa City.

Martin, G.W., Alexopoulos, C.J. \& Farr, M. L. 1983. The genera of Myxomycetes. University of Iowa Press, Iowa City.

Penhalber, E. F. \& Mantovani, W. 1997. Floração e chuva de sementes em mata secundária em São Paulo, SP. Revista Brasileira de Botânica 20: 205-220.

Poulain, M., Meyer, M. \& Bozonnet, J. 2011.Les Myxomycètes. Fédération Mycologique et Botanique Dauphiné-Savoie, Sévrier.

Shirasuna, R.T. \& Filgueiras, T. S. 2013. Bambus nativos (Poaceae, Bambusoideae) no Parque Estadual das Fontes do Ipiranga (São Paulo, SP, Brasil). Hoehnea 40: 315-359. 